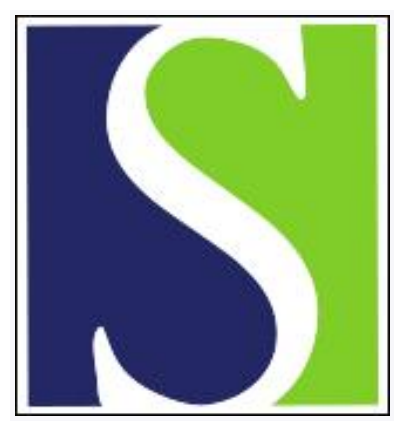

Scand J Work Environ Health 2003;29(3):189-196

https://doi.org/10.5271/sjweh.721

Issue date: Jun 2003

Magnetic resonance imaging findings in respect to carpal tunnel syndrome

by Pasternack II, Malmivaara A, Tervahartiala P, Forsberg H, Vehmas T

Affiliation: FinOHTA/STAKES, PO Box 220, FIN 00531 Helsinki, Finland. iris.pasternack@stakes.fi

Key terms: arm; carpal tunnel syndrome; diagnostic imaging; epidemiologic research design; magnetic resonance imaging; mononeuropathy; MRI; review; systematic review

This article in PubMed: www.ncbi.nlm.nih.gov/pubmed/12828388 


\title{
Magnetic resonance imaging findings in respect to carpal tunnel syndrome
}

\author{
by Iris I Pasternack, MD, ,2, Antti Malmivaara, DMedSci, ${ }^{1}$ Pekka Tervahartiala, DMedSci, ${ }^{3}$ Henry Fors- \\ berg, MD, ${ }^{1,4}$ Tapio Vehmas, DMedSci ${ }^{1}$
}

\begin{abstract}
Pasternack II, Malmivaara A, Tervahartiala P, Forsberg H, Vehmas T. Magnetic resonance imaging findings in respect to carpal tunnel syndrome. Scand J Work Environ Health 2003;29(3):189-196.

The objective of this systematic review was to examine the technical and diagnostic capability of magnetic resonance imaging (MRI) to identify carpal tunnel syndrome (CTS). Two independent authors retrieved and screened the existing data and extracted the clinical and validity data adhering to predefined inclusion criteria. The MRI methods and findings were analyzed by two experienced radiologists. Disagreements were solved in consensus. The MRI findings of 373 affected wrists in 13 studies were compared with asymptomatic referents or a series of patients with non-CTS wrist pain. Increased T2-signal, cross-sectional area, and flattening of the median nerve inside the carpal tunnel, as well as bowing of the flexor retinaculum, were the most frequently occurring signs in CTS. Reliable assessment of the sensitivity and specificity of certain MRI signs in respect to CTS remained difficult due to study heterogeneity. There is an obvious need for imaging studies in which validated diagnostic criteria are used.
\end{abstract}

Key terms arm, diagnostic imaging, epidemiologic research design, mononeuropathies, systematic review.

Carpal tunnel syndrome (CTS) is a disabling condition characterized by pain and paresthesias of the hand and forearm, caused by median nerve neuropathy in the wrist. In 1997 the prevalence rate for clinically certain CTS in the Swedish general population was $2.8 \%$ for men and $4.6 \%$ for women (1). The dominant hand is affected more frequently, and reports of bilateral involvement range from $7 \%$ to $80 \%(2-4)$.

Several inflammatory (traumatic synovitis, rheumatoid arthritis), metabolic (diabetes, amyloidosis, hypothyreoidism), and physiological processes (pregnancy, menopause, work-related hypertrophy of muscles and tendons), as well as space-occupying lesions and congenital abnormalities that either narrow the carpal tunnel or increase the pressure within it, can result in entrapment of the median nerve (5). Another possible mechanism is circulatory disturbance in the nerve, whether due to ischemia or venous congestion (6).
The diagnosis of CTS is often based on typical symptoms alone. Tinel's sign and Phalen's test are prone to false-positive and false-negative results (5). From $53 \%$ to $98 \%$ of patients with clinically diagnosed CTS have abnormalities in nerve conduction tests (7). Imaging techniques had minor importance in the assessment of CTS before the introduction of magnetic resonance imaging (MRI) (8).

Although MRI is not used in the routine diagnosis of CTS, there are some important justifications for an imaging technique able to reveal macroscopic CTS-specific neural and other soft tissue changes and bony details. Ideally, MRI would distinguish cases refractory to conservative treatment at an early stage, enabling patients' more accurate allocation to surgery. In clinical research and compensation decisions, documented images allow for more objective follow-up. Detailed and repeated anatomic imaging may also clarify the pathogenesis of CTS.

Finnish Institute of Occupational Health, Helsinki, Finland.

FinOHTA/STAKES, Helsinki, Finland.

Department of Radiology, Helsinki University Central Hospital, Helsinki, Finland.

Helsinki Health Center, Helsinki, Finland.

Reprint requests to: Dr Iris I Pasternack, FinOHTA/STAKES, PO Box 220, FIN-00531 Helsinki, Finland. [E-mail: iris.pasternack@stakes.fi] 
Our objective was to review the medical literature systematically to determine what is known about the technical and diagnostic performance of MRI in relation to CTS.

\section{Subjects and methods}

All studies in which patients with CTS were imaged with magnetic resonance were included in the review. Excluded were reviews, studies with small samples of less than 10 patients, and studies on CTS due to trauma, rheumatoid arthritis, gout, or tumors only. Where the same or partly the same results were presented in two or more publications, the most recent publication was chosen for the review.

We prepared structured forms for clinical and imaging data extraction, clinical relevance, and internal validity by adapting the recommendations of the Cochrane Methods Working Group on Systematic Review of Screening and Diagnostic Tests (9).

The literature search included the following databases: Embase, Nioshtic, Cisdoc, Hseline until 3/1999, DARE, CCTR version 4/2002, and Medline until 12/ 2001 (PubMed). The search strategy combined the index terms "carpal tunnel syndrome" and "magnetic resonance imaging".

Two independent reviewers (IP, HF) selected the studies first by title, then by abstract, and finally by the whole text. The reference lists of the pertinent articles were screened. The reviewers then extracted the clinical data and assessed the validity and clinical relevance of the studies included. Two radiologists (PT, TV), both with several years of experience with MRI, analyzed the imaging methods and findings independently. The interrater agreement on the assessments of external and internal validity was not measured. Disagreements were solved in consensus.

We scored the external validity criteria of the included studies (documentation of the reference diagnosis and the clinical characteristics of the patients and referents) on a scale from 0 to 9 according to the fulfillment of the following questions: (i) were any of the existing consensus criteria for CTS applied (4, 10-13), (ii) were the symptoms described, (iii) were the clinical findings described, (iv) was a nerve conduction study (NCS) included, (v) was the severity of the disease graded, (vi) were the patient exclusion criteria stated, (vii) were the comorbid conditions stated, (viii) were the hand-loading activities described, and (ix) were any possible invasive treatments of the forearm described? The score for the internal validity of the study method (scale 0-3) was based on the following aspects: (i) blinding of the magnetic resonance image interpretation, (ii) interob- server or intraobserver agreement concerning the image assessment, and (iii) comparability between the cases and referents. Cases and referents were considered comparable in their age and gender distribution if the mean ages or gender ratios of the referents were within a $10 \%$ range of the corresponding values of the cases. The two studies $(14,15)$ in which the referents represented a relevant consecutive series of patients with similar symptoms of CTS and the three studies (16-18) that used the contralateral symptom-free wrist of the patient as reference were scored for comparability.

The MRI method score (0-10) included the description of the following factors: (i) field strength, (ii) coil type, (iii) arm-wrist position, (iv) imaging direction, (v) pulse sequences, (vi) times to repetition, times to echo and flip angle, (vii) number of acquisitions, (viii) slice thickness, (ix) gap between slices, and (x) pixel size or field of view/matrix size. The image quality of the figures was rated as $0=$ poor, $1=$ fair, $2=$ good, or $3=$ excellent. Agreement concerning the radiologists' ratings of image quality was computed with the intraclass correlation (weighted kappa). Spearman's correlation (rs) was used to correlate the year of publication, magnetic field strength, method scores, number of sequences, and mean image quality with each other. SPSS 10.0 software (SPSS Inc, Chicago, Il, USA) was used.

The reviewers evaluated the following MRI findings: median nerve dimensions, median nerve flattening, median nerve signal intensity, contrast enhancement of the median nerve, bowing of the flexor retinaculum, dimensions of the carpal tunnel, peritendon or synovial pathology, possible anatomic variations, and other pathology. The existence of these signs was tabulated, and the statistically significant difference between the study group and the reference group was noted. If the statistically significant difference was not given in the original article, we used Fisher's exact test for retrospective testing whenever possible. We paid attention to whether quantitative measurements or merely subjective estimations were presented.

\section{Results}

Thirteen studies, with a total of 509 affected wrists in 373 patients with CTS, were left for final assessment (7, 8, 10-21). The number of referents was 407, 192 of whom were healthy volunteers (287 wrists in 9 of 13 studies), 42 of whom were the study patients (49 contralateral symptom-free wrists of patients in 2 of 13 studies), and 173 of whom were symptomatic referemce patients imaged for a wrist pathology other than CTS (173 wrists in 2 of 13 studies). One study used double references (ie, both healthy volunteers and contralateral 
symptom-free hands as a comparison for the diseased hand).

The gender distribution and the mean ages, as well as the scores for internal validity, are presented in table 1. The internal validity score correlated positively with the year of publication ( $\mathrm{rs}=0.57, \mathrm{P}=0.041$ ). The clinical features of the patients and the means of diagnosing their CTS were described incompletely in all of the original studies (tables 2 and 3). In most studies, the diagnosis of CTS was verified by means of pathological nerve conduction studies. The study of Brahme et al (8), in contrast, included only patients with normal nerve conduction studies. In three studies, the findings of the pa- tients' nerve conduction studies were either pathological or normal.

The MRI findings are summarized in table 4. Five studies applied only qualitative estimations, whereas most studies ( 8 of 13) used quantitative measurements at least for some of the magnetic resonance parameters (dimensions or signal intensities). Statistically significant differences between the CTS patients and the referents were found for the following median nerve abnormalities: enlargement of the cross-sectional area (4 studies), flattening (3 studies), a combination of enlargement and flattening (1 study), and an increased T2 signal (7 studies). Other statistically significant pathological

Table 1. Internal validity criteria used in the included studies. [CTS/op = magnetic resonance (MR) images of the affected wrist(s) of the patients with carpal tunnel syndrome (CTS) compared with MR images of the wrists of patients with other wrist pathologies; CTS/hv = MR images of the affected wrist(s) of the patients with CTS compared with MR images of the wrists of healthy volunteers; CTS/ clw = MR images of the affected wrist(s) of the CTS patients compared with MR images of the symptom-free contralateral wrists of the same patients; NCS+/NCS - = wrists with pathological nerve conduction studies (NCS) compared with wrists with normal NCS, irrespective of symptoms, $\mathrm{N}$ = number of persons, $\mathrm{W}$ = number of wrists]

\begin{tabular}{|c|c|c|c|c|c|c|c|c|c|c|c|c|c|c|}
\hline \multirow[t]{3}{*}{ Study } & \multirow{3}{*}{$\begin{array}{l}\text { Type of } \\
\text { compari- } \\
\text { sion }\end{array}$} & \multicolumn{2}{|c|}{ Patients } & \multicolumn{2}{|c|}{ Referents } & \multicolumn{6}{|c|}{$\begin{array}{l}\text { Comparability of referents or referents representing } \\
\text { a relevant clinical population }\end{array}$} & \multirow{3}{*}{$\begin{array}{l}\text { Score of } \\
\text { blinded } \\
\text { assessment }\end{array}$} & \multirow{3}{*}{$\begin{array}{l}\text { Score of } \\
\text { inter-intra- } \\
\text { observer } \\
\text { agreement }\end{array}$} & \multirow{3}{*}{$\begin{array}{l}\text { Overall score } \\
\text { for internal } \\
\text { validity }(0-3)\end{array}$} \\
\hline & & \multirow{2}{*}{$\mathrm{N}$} & \multirow[t]{2}{*}{ W } & \multirow[t]{2}{*}{$\mathrm{N}$} & \multirow[t]{2}{*}{ W } & \multicolumn{2}{|c|}{ Male:female ratio } & \multicolumn{2}{|c|}{ Mean age (years) } & \multirow[t]{2}{*}{ Other } & \multirow[t]{2}{*}{ Score } & & & \\
\hline & & & & & & Patients & Referents & Patients & Referents & & & & & \\
\hline $\begin{array}{l}\text { Bonél et al, } \\
2001 \text { (14) }\end{array}$ & CTS/ op & 22 & 22 & 30 & 30 & $?$ & $?$ & $?$ & $?$ & $\begin{array}{l}\text { Referents had sus- } \\
\text { pected wrist injuries } \\
(25 \text { of } 30) \text {, osteo- } \\
\text { necrosis }(3 \text { of } 30) \text { and } \\
\text { tumors ( } 2 \text { of } 30)\end{array}$ & 1 & 1 & 1 & 3 \\
\hline $\begin{array}{l}\text { Zagnoli et al, } \\
1999 \text { (18) }\end{array}$ & $\begin{array}{l}\text { CTS/hv (10) } \\
\text { CTS/clw (7) }\end{array}$ & 20 & 33 & 173 & 34 & 1.9 & $?$ & 51 & $?$ & $\begin{array}{l}\text { Age and gender } \\
\text { matched, referents with } \\
\text { no history of symptoms }\end{array}$ & 1 & 0 & 1 & 2 \\
\hline $\begin{array}{l}\text { Keindienst } \\
\text { et al, } 1998 \\
\text { (21) }\end{array}$ & CTS/hv & 77 & 81 & 18 & 18 & 0.2 & 0.2 & 54 & 51 & Healthy volunteers & 1 & 0 & 0 & 1 \\
\hline $\begin{array}{l}\text { Allman et al, } \\
199720)\end{array}$ & CTS/hv & 19 & 20 & 17 & 20 & 0.6 & 0.4 & 50 & 43 & Healthy volunteers & 0 & 1 & 0 & 1 \\
\hline $\begin{array}{l}\text { Bak et al, } \\
199716)\end{array}$ & $\begin{array}{l}\text { CTS/clw 12) } \\
\text { NCS+/NSG- } \\
\text { (18/22) }\end{array}$ & 20 & 28 & .. 1 & 12 & 0.8 & 0.8 & $?$ & $?$ & Contralateral hand & 1 & 1 & 0 & 2 \\
\hline $\begin{array}{l}\text { Brahme et al, } \\
1997 \text { (8) }\end{array}$ & CTS/hv ${ }^{a}$ & 20 & 21 & 15 & 15 & 0.1 & 1.1 & 37 & 35 & $\begin{array}{l}\text { Asymptomatic } \\
\text { volunteers }\end{array}$ & 0 & 1 & 0 & 1 \\
\hline $\begin{array}{l}\text { Pierre- } \\
\text { Jerome et al, } \\
1997 \text { (25) }\end{array}$ & CTS/hv & 26 & 52 & 28 & 56 & 0 & 0 & 52 & 45 & $\begin{array}{l}\text { All women with } \\
\text { similar exclusion } \\
\text { criteria }\end{array}$ & 1 & 1 & 0 & 2 \\
\hline $\begin{array}{l}\text { Radack et al, } \\
1997 \text { (15) }\end{array}$ & CTS/op & 22 & .. & 143 & .. & 0.9 & $?$ & 40 & 37 & $\begin{array}{l}\text { Consecutive clinical } \\
\text { series with various } \\
\text { wrist pathologies }\end{array}$ & 1 & 1 & 1 & 3 \\
\hline $\begin{array}{l}\text { Pierre- } \\
\text { Jerome et al, } \\
1996 \text { (24) }\end{array}$ & CTS/hv & 641 & 128 & 541 & 108 & 0 & 0 & 45 & 42 & $\begin{array}{l}\text { Healthy women as } \\
\text { volunteers, no trauma } \\
\text { or systemic disease }\end{array}$ & 1 & $\begin{array}{l}?(\text { com- } \\
\text { puteriz- } \\
\text { ed) }\end{array}$ & 0 & 1 \\
\hline $\begin{array}{l}\text { Britz et al, } \\
1995 \text { (7) }\end{array}$ & CTS/hv & 32 & 43 & 5 & 5 & $?$ & $?$ & $?$ & $?$ & $\begin{array}{l}\text { Asymptomatic } \\
\text { volunteers }\end{array}$ & 0 & 0 & 0 & 0 \\
\hline $\begin{array}{l}\text { Buchberger } \\
\text { et al, } 1992(19\end{array}$ & $\begin{array}{l}\text { CTS/hv } \\
\text { 9) }\end{array}$ & 18 & 20 &.. & 28 & 0.3 & $?$ & 57 & $?$ & $\begin{array}{l}\text { Referents from a pre } \\
\text { liminary study }\end{array}$ & 0 & 1 & 0 & 1 \\
\hline $\begin{array}{l}\text { Soccetti et al, } \\
1992(17)\end{array}$ & CTS/clw & 23 & 23 &.. & 23 & $?$ & $?$ & $?$ & $?$ & Contralateral hand & 1 & 0 & 0 & 1 \\
\hline $\begin{array}{l}\text { Mesgarzadeh } \\
\text { et al, 1989 } \\
(22,23)\end{array}$ & CTS/hv & 10 & 14 & 17 & 17 & 0.6 & $?$ & 37 & $?$ & $\begin{array}{l}\text { Referents from a pre } \\
\text { liminary study }\end{array}$ & 0 & 1 & 0 & 1 \\
\hline
\end{tabular}

\footnotetext{
a Preexcercise MR images compared with postexcercise MR images.
} 
Table 2. Description of the symptoms described, status or provocation tests described, pathological nerve conduction studies, consensus criteria, and severity grading of the patients in the included studies. (MRI = magnetic resonance imaging, NCS=nerve conduction study, NM=not mentioned, CTS=carpal tunnel syndrome)

\begin{tabular}{|c|c|c|c|c|c|c|}
\hline Study & $\begin{array}{l}\text { Symptoms } \\
\text { described }\end{array}$ & $\begin{array}{l}\text { Status or provocation } \\
\text { tests described }\end{array}$ & $\begin{array}{l}\text { Pathological } \\
\text { NCS } \\
(\%)\end{array}$ & $\begin{array}{l}\text { Consensus } \\
\text { criteria }\end{array}$ & Severity grading & Exclusion criteria \\
\hline Bonél et al, 2001 (14) & No & No & $100(?)$ & No & NM & $\begin{array}{l}\text { Rheumatoid arthritis and other } \\
\text { inflammatory diseases }\end{array}$ \\
\hline Zagnoli et al, 1999 (18) & Yes & No & 94 & No & $\begin{array}{l}\text { Own staging system: clinical } \\
\text { severity: } 13 \text { mild, } 12 \text { moderate, } \\
8 \text { severe; NCS: } 2 \text { normal, } 10 \text { mild, } \\
12 \text { moderate, } 9 \text { severe }\end{array}$ & NM \\
\hline $\begin{array}{l}\text { Keindienst et al, } 1998 \\
\text { (21) }\end{array}$ & Yes & No & 100 & $\begin{array}{l}\text { Symptoms } \\
\text { and NCS }{ }^{a}\end{array}$ & $\begin{array}{l}\text { Gelberman grading: } 22 \text { early, } \\
42 \text { intermediate, } 17 \text { advanced }\end{array}$ & NM \\
\hline Allman et al, 1997 (20) & No & No & 100 & No & NM & NM \\
\hline Bak et al, 1997 (16) & No & No & 45 & No & NM & $\begin{array}{l}\text { Diabetes, severe renal disease, } \\
\text { pregnancy < } 1 \text { year, previous CTS, } \\
\text { contraindications to MRI, } \\
\text { polyneuropathy }\end{array}$ \\
\hline Brahme et al, 1997 (8) & No & Yes & 0 & No & NM & NM \\
\hline $\begin{array}{l}\text { Pierre-Jerome et al, } \\
1997 \text { (25) }\end{array}$ & Yes & Yes & 100 & $\begin{array}{l}\text { Symptoms } \\
\text { and NCS }{ }^{b}\end{array}$ & $\begin{array}{l}\text { Mean duration } 3.0 \text { (range } \\
1-6 \text { ) years }\end{array}$ & $\begin{array}{l}\text { Connective tissue disease, } \\
\text { previous CTS surgery, alcohol- } \\
\text { ism, }{ }^{\circ} \text { history of trauma }\end{array}$ \\
\hline Radack et al, 1997 (15) & No & No & 100 & $\begin{array}{l}\text { Stevens } \\
\text { (NCS) }\end{array}$ & NM & NM \\
\hline $\begin{array}{l}\text { Pierre-Jerome et al, } \\
1996 \text { (24) }\end{array}$ & No & No & $?$ & No & NM & $\begin{array}{l}\text { Concominant systemic diseases, } \\
\text { psychiatric disorders }\end{array}$ \\
\hline Britz et al, 1995 (7) & Yes & Yes & 95 & No & $\begin{array}{l}1 \text { of } 43 \text { mild, } 35 \text { of } 43 \text { moderate, } \\
7 \text { of } 43 \text { severe }\end{array}$ & NM \\
\hline $\begin{array}{l}\text { Buchberger et al, } \\
1992 \text { (19) }\end{array}$ & Yes & Yes & 100 & No & Severe 10/18 & NM \\
\hline Soccetti et al, 1992 (17) & No & No & 100 & No & NCS: intermediate & $\begin{array}{l}\text { Contralateral signs of neurologic } \\
\text { damage }\end{array}$ \\
\hline $\begin{array}{l}\text { Mesgarzadeh et al, } \\
1989(22,23)\end{array}$ & No & No & $?$ & No & NM & NM \\
\hline
\end{tabular}

${ }^{a}$ Diagnostic criteria by Gelberman et al (see reference 13).

${ }^{b}$ Practice parameters for electrodiagnostic studies in CTS by American Academy of Neurology (see reference 10).

c Mayfield 1974 criteria.

${ }^{\mathrm{d}}$ Bectrodiagnostic criteria by Stevens (see reference 4).

findings among the CTS patients included flexor retinaculum bowing (6 studies), synovial swelling (1 study), and the presence of anatomic variants - an absent hamulus, median nerve interposition, and double branching of the median nerve (1 study).

Nine studies gave dichotomous qualitative estimations of the occurrence of the previously mentioned magnetic resonance findings among the patients and referents. We used these data to calculate the sensitivities and specificities. For enlargement of the crosssectional area of the median nerve, the sensitivity was $35 \%$ and the specificity was $84 \%$. The corresponding values were $54 \%$ and $95 \%$ for median nerve flattening, $70 \%$ and $93 \%$ for flexor retinaculum bowing, and $75 \%$ and $66 \%$ for an increased T2-signal intensity of the median nerve.

The studies of Bonel et al (14) and Radack et al (15), which had the highest validity scores, used a relevant clinical patient population with various wrist pathologies as their referents. The results of these studies are very similar to the overall results. Similarly, the results of a larger subgroup of studies with internal validity scores of 2 or 3 (5 studies) did not deviate from the average. The three studies with apparently different results $(16,17,21)$ did not represent any special quality category. Their internal validity scores were 1,2 , and 1 , with external validity scores of 5, 2 and 3 and MRI method scores of 9,9 and 7 .

High-field MRI equipment $(\geq 1.0 \mathrm{~T})$ was used in 10 studies, and to some extent in one of the remaining three studies. The MRI method was described well, the scores ranging from 3 to 10 and the median being 9 (table 5). The readers agreed on 11 of 13 image quality ratings and disagreed on two; no disagreement was greater than one score (intraclass correlation 0.80 ). No significant correlations were found between the methodology variables. 
Table 3. Description of the comorbid conditions, hand loading activities, and invasive treatment prior to the magnetic resonance imaging $(\mathrm{MRI})$ of the patients in the included studies and the total external valitity score of the studies. $(\mathrm{NM}=$ not mentioned, NCS = nerve conduction study, CTS = carpal tunnel syndrome)

\begin{tabular}{|c|c|c|c|c|c|}
\hline Sudy & $\begin{array}{l}\text { Comorbid } \\
\text { conditions }\end{array}$ & $\begin{array}{l}\text { Hand loading } \\
\text { activities }\end{array}$ & $\begin{array}{l}\text { Invasive treatment } \\
\text { prior to MRI }\end{array}$ & $\begin{array}{l}\text { tal external } \\
\text { idity score } \\
\text {-9) }\end{array}$ & Notes \\
\hline Bonél et al, 2001 (14) & $\mathrm{NM}$ & NM & $7(32 \%)$ operated on & 3 & $\begin{array}{l}\text { Median nerve caliber enlargement and flexor } \\
\text { retinaculum bowing important }\end{array}$ \\
\hline $\begin{array}{l}\text { Zagnoli et al, } \\
1999(18)\end{array}$ & $\mathrm{NM}$ & $\mathrm{NM}$ & $19(57.5 \%)$ operated on & 4 & $\begin{array}{l}\text { Oinical and NCS findings discordant in } 47.5 \% \text {; } \\
\text { flexor retinaculum bowing correlated with mild } \\
\text { or absent symptoms; median nerve dimension and } \\
\text { signal intensity increased correlates with moderate } \\
\text { or severe symptoms }\end{array}$ \\
\hline $\begin{array}{l}\text { Keindienst et al, } \\
1998(21)\end{array}$ & $\mathrm{NM}$ & NM & \multicolumn{2}{|l|}{$\begin{array}{l}26 \text { (34\%) patients ( } 7 \text { early, } \\
15 \text { intermediate, } 4 \text { advanced) } \\
\text { had had } 1-17 \text { (mean } 4.8 \text { ) } \\
\text { steroid injections }\end{array}$} & $\begin{array}{l}\text { In advanced disease median nerve edema may have } \\
\text { disappeared and the signal intensity fallen; thus } \\
\text { signal intensity may not have been the only } \\
\text { magnetic resonance criterion in CTS; the MRI } \\
\text { findings correlated with the Gelberman severity } \\
\text { grading (13) }\end{array}$ \\
\hline Alman et al, 1997 (20) & NM & NM & NM & 1 & $\begin{array}{l}18 \text { patients were operated on after MRI; all had } \\
\text { partial or complete clinical benefit; } 67 \% \text { of them } \\
\text { had more than a } 10 \% \text { decrease in the T2-signal }\end{array}$ \\
\hline Bak et al, 1997 (16) & $\mathrm{NM}$ & NM & NM & 2 & $\begin{array}{l}\text { No correlation between the NCS and MRI } \\
\text { parameters }\end{array}$ \\
\hline Brahme et al, 1997 (8) & $\mathrm{NM}$ & Occupational & NM & 3 & $\begin{array}{l}\text { Dynamic CTS; MRI was done prior to and imme- } \\
\text { diately after a 10-minute provocative exercise; at } \\
\text { least one MR parameter worsened in } 86 \% \text { of the } \\
\text { patients and } 40 \% \text { of the referents }\end{array}$ \\
\hline $\begin{array}{l}\text { Pierre-Jerome et al, } \\
1997 \text { (25) }\end{array}$ & NM & $\mathrm{NM}$ & NM & 6 & $\begin{array}{l}\text { No difference in carpal tunnel volume between the } \\
\text { patients and referents; the narrowest focal point } \\
\text { was also equally located near the canal outlet }\end{array}$ \\
\hline Radack et al, 1997 (15) & $\mathrm{NM}$ & $\mathrm{NM}$ & NM & 3 & $\begin{array}{l}\text { The diagnosis of CTS was based on observations } \\
\text { in the follow-up of a relevant population, with a } \\
13 \% \text { prevalence of CTS }\end{array}$ \\
\hline $\begin{array}{l}\text { Pierre-Jerome et al, } \\
1996 \text { (24) }\end{array}$ & $\begin{array}{l}\text { Some had } \\
\text { rheumatoid } \\
\text { arthritis }\end{array}$ & $\mathrm{NM}$ & None had had surgery & 3 & $\begin{array}{l}\text { Anatomic variants: intracarpal double branching of } \\
\text { the median nerve in } 14 \text { wrists with CTS and } 4 \\
\text { reference wrists; median nerve interposition } \\
\text { between the flexor pollicis longus and the super- } \\
\text { ficial flexor tendon of the index finger in } 4 \text { patients } \\
\text { with CTS and } 1 \text { referent }\end{array}$ \\
\hline Britz et al, 1995 (7) & $\mathrm{NM}$ & NM & NM & 4 & $\begin{array}{l}\text { MRI correlated well with clinical, NCS, and opera- } \\
\text { tive findings }\end{array}$ \\
\hline $\begin{array}{l}\text { Buchberger et al, } \\
1992 \text { (19) }\end{array}$ & $\mathrm{NM}$ & NM & NM & 4 & $\begin{array}{l}\text { MRI served as gold standard for the sonogram } \\
\text { measurements }\end{array}$ \\
\hline $\begin{array}{l}\text { Soccetti et al, } 1992 \\
\text { (17) }\end{array}$ & $\mathrm{NM}$ & NM & NM & 3 & $\begin{array}{l}\text { MRI findings did not correlate with the NCS } \\
\text { findings }\end{array}$ \\
\hline $\begin{array}{l}\text { Mesgarzadeh et al, } \\
1989(22,23)\end{array}$ & $\begin{array}{l}1 \text { rheumatoid } \\
\text { arthritis } \\
\text { (bilateral) }\end{array}$ & $\begin{array}{l}3 \text { engaged in work } \\
\text { that may have caus- } \\
\text { ed CTS (clerk, typist, } \\
\text { barber), } 3 \text { had un- } \\
\text { usual upper-limb ac- } \\
\text { tivity (painting, ham- } \\
\text { mering, racket sports) }\end{array}$ & 4 operated on & 3 & $\begin{array}{l}\text { An increase in median nerve cross-section of up } \\
\text { to two- to threefold as it entered carpal tunnel } \\
\text { in the pisiform level indicated CTS the best }\end{array}$ \\
\hline
\end{tabular}

\section{Discussion}

An increased T2-signal intensity in the median nerve and bowing of the flexor retinaculum seem to be the most sensitive magnetic resonance signs in CTS. Other potential signs are an increased cross-sectional area, flattening of the median nerve, and peritendon pathology.

Previous nonsystematic reviews on MRI in respect to CTS $(5,26)$ found problems similar to ours as regards the design of the original studies: poor description of the reference diagnosis and recruitment of asymptomatic referents only.

There are several classifications or consensus criteria for CTS, including symptoms, clinical findings, and electrophysiological criteria (4, 10-13). Different diagnostic criteria lead to differences in patient spectra, and such differences certainly have some effect on estimates of test accuracy (27). Therefore we would have expected moreadequate descriptions of the symptoms and signs of the 
Table 4. Summary of the magnetic resonance imaging (MRI) findings in the included studies. ${ }^{a}(+/+=$ increased value of the parameter or presence of the sign, $-/-=$ decreased value of the parameter or absence of the sign, $+-/+-=$ indifferent, ${ }^{*}=$ statistically significant difference when compared with referents as reported in the article or calculated afterwards, $\left({ }^{*}\right)=$ some of the recorded values significant, $\mathrm{R}=$ flexor retinaculum, $\mathrm{CT}=$ carpal tunnel)

\begin{tabular}{|c|c|c|c|c|c|c|c|c|c|}
\hline \multirow[t]{2}{*}{ Study } & \multicolumn{4}{|c|}{ Median nerve } & \multirow{2}{*}{ R bowing } & \multirow{2}{*}{$\begin{array}{l}\text { CT } \\
\text { dimensions }\end{array}$} & \multirow{2}{*}{$\begin{array}{l}\text { (Peri)tendon } \\
\text { pathology }\end{array}$} & \multirow{2}{*}{$\begin{array}{l}\text { Anatomical } \\
\text { variants }\end{array}$} & \multirow{2}{*}{$\begin{array}{l}\text { Other } \\
\text { pathology }\end{array}$} \\
\hline & $\begin{array}{l}\text { Cross-sec- } \\
\text { tional area }\end{array}$ & Pattening & $\begin{array}{l}\text { T2- } \\
\text { signal }\end{array}$ & $\begin{array}{l}\text { Contrast } \\
\text { enhancement }\end{array}$ & & & & & \\
\hline Bonél et al, 2001 (14) & $+^{*}$ & + & $+^{*}$ & $t^{*}$ & $+^{*}$ & & & & \\
\hline Zagnoli et al, 1999 (18) & + & $+^{*}$ & $+^{*}$ & & $t^{*}$ & & & & \\
\hline Keindienst et al, 1998 (21) & + & +- & $+\left({ }^{*}\right)$ & & & & & & Fuid in CT \\
\hline Allman et al, 1997 (20) & $+\left({ }^{*}\right)$ & $+:$ & $+\left(^{*}\right)$ & & $+^{*}$ & - & & & \\
\hline Bak et al, 1997 (16) & +- & - & & & + & & & & \\
\hline Brahme et al, 1997 (8) & + & $+^{*}$ & $t^{*}$ & & $t^{*}$ & & $+^{*}$ & & Fuid in CT \\
\hline Pierre-Jerome et al, 1997 (25) & & & $+^{*}$ & & & - & & & \\
\hline Radack et al, 1997 (15) & + & + & + & & $+^{*}$ & & & & \\
\hline Pierre-Jerome et al, 1996 (24) & & & & & & & & $+^{*}$ & \\
\hline Britz et al, 1995 (7) & $t^{*}$ & $+^{*}$ & & + & & + & & & \\
\hline Buchberger et al, 1992 (19) & + & + & + & & + & & + & & Ganglions \\
\hline Soccetti et al, 1992 (17) & +- & & + & & & & + & + & \\
\hline Mesgarzadeh et al, $1989(22,23)$ & $+^{*}$ & $t^{*}$ & + & & $+^{*}$ & & + & & \\
\hline
\end{tabular}

a Symbols in lightface indicate estimated assessment and those in boldface indicate measured assessment.

Table 5. Summary of the technical magnetic resonance imaging (MRI) data in the included studies.

\begin{tabular}{|c|c|c|c|c|}
\hline Study & $\begin{array}{l}\text { Feld } \\
\text { strength } \\
\text { (T) }\end{array}$ & $\begin{array}{l}\text { Description } \\
\text { of MRI } \\
\text { method (0-10) }\end{array}$ & $\begin{array}{l}\text { Number of } \\
\text { sequences or } \\
\text { directions }\end{array}$ & $\begin{array}{l}\text { Image } \\
\text { quality } \\
(0-3)\end{array}$ \\
\hline $\begin{array}{l}\text { Bonél et al, } \\
2001 \text { (14) }\end{array}$ & 0.2 & 9 & $5-6$ & 2 \\
\hline $\begin{array}{l}\text { Zagnoli et al, } \\
1999 \text { (18) }\end{array}$ & 1.0 & 6 & $2-3$ & 1 \\
\hline $\begin{array}{l}\text { Keindienst et al, } \\
1998 \text { (21) }\end{array}$ & 1.5 & 9 & 1 & 2 \\
\hline $\begin{array}{l}\text { Allman et al, } \\
1997(20)\end{array}$ & 1.0 & 9 & 3 & 2 \\
\hline $\begin{array}{l}\text { Bak et al, } \\
1997 \text { (16) }\end{array}$ & 1.5 & 9 & 2 & 2 \\
\hline $\begin{array}{l}\text { Brahme et al, } \\
1997 \text { (8) }\end{array}$ & 1.5 & 10 & 1 & 2 \\
\hline $\begin{array}{l}\text { Pierre-Jerome } \\
\text { et al, } 1997 \text { (25) }\end{array}$ & 0.5 & 10 & 1 & 1.5 \\
\hline $\begin{array}{l}\text { Radack et al, } \\
1997 \text { (15) }\end{array}$ & 1.5 & 9 & 2 & 3 \\
\hline $\begin{array}{l}\text { Pierre-Jerome } \\
\text { et al, } 1996 \text { (24) }\end{array}$ & $0.5 \& 1.5$ & 8 & $1-2$ & 2 \\
\hline $\begin{array}{l}\text { Britz et al, } 1995 \\
\text { (7) }\end{array}$ & 1.5 & 3 & 2 & 2 \\
\hline $\begin{array}{l}\text { Buchberger et al, } \\
1992 \text { (19) }\end{array}$ & 1.5 & 7 & 3 & 1.5 \\
\hline $\begin{array}{l}\text { Soccetti et al, } \\
1992 \text { (17) }\end{array}$ & 1.0 & 7 & 3 & 1 \\
\hline $\begin{array}{l}\text { Mesgarzadeh et al, } \\
1989(22,23)\end{array}$ & 0.3 & 9 & 2 & 1 \\
\hline
\end{tabular}

patients included in the original studies. The study of Bak et al (16) was the only one in which the result of the nerve conduction test did not affect inclusion in the study. Twenty patients with suspected CTS were studied prospectively to determine whether specific parameters measured on magnetic resonance images correlated with the nerve conduction test results. No such correlation was found, but neither did the patients have any enlargement in the cross-sectional area of the median nerve; instead of flattening, the nerve seemed rather rounded. This finding may have given rise to speculations about diverse pathophysiological mechanisms behind CTS or diverse stages of chronicity of the disease affecting the imaging outcome. In acute inflammation the tissues are usually swollen, while in chronic conditions there may be little change in tissue volume.

There is evidence that insufficient documentation of the clinical characteristics tends to cause estimates of test accuracy to be exaggerated, whereas insufficient documentation of the reference diagnosis tends to cause their underestimation (27). Insufficient blinding and an inadequate description of the results tend to cause test accuracy to be exaggerated. A great interobserver variation, in turn, is related to the low sensitivity and specificity of a test (27). In this review, we saw no great variability in the occurrence of magnetic resonance signs between studies with low and high validity scores.

The appropriateness of the case-referent design in diagnostic studies has been questioned. When diagnostic test results are compared between diseased and healthy persons, the mild cases-which are difficult to diagnose-are often screened out. The outcome is 
spectrum bias, which tends to increase both the sensitivity and specificity of the test. In this review, the two studies that used contralateral symptom-free hands as reference $(16,17)$ showed no sign of enlargement of the cross-sectional area of the median nerve, a sign that occurs frequently in studies in which healthy volunteers serve as referents. Such findings may be related to constitutional factors or aging rather than to CTS. Another setting, represented by two studies in this review (14, 15), is a prospective consecutive series of a relevant clinical population with suspected disease. All of the patients undergo an imaging test and their diagnosis is assessed according to proper consensus criteria during the follow-up. Age, gender, occupation, and other activities alongside the comorbid conditions are all relevant sources of bias when wrists affected with CTS and symptom-free wrists are compared. As long as there is no perfect gold standard for the diagnosis of CTS, any other disease that causes symptoms similar to those of CTS in the forearm can be considered a confounding factor. This kind of study, in which referents represent a clinical population with suspected disease, overcomes these difficulties and can be seen as more relevant to clinical practice.

In presenting the imaging results (table 4), a distinction was drawn between MRI assessments based on quantitative measurements and those based on subjective impressions. This important issue of study validity was not employed in the validity scorings, and therefore may be a weakness of this review. Due to the heterogeneity of the studies in terms of reference diagnosis and type of control group, as well as the small sample size, the values for sensitivity and specificity calculated in this review should be considered with caution. Because of this apparent heterogeneity, we decided not to dichotomize all the data and pool it to obtain a summary receiver operating characteristic curve (28). There are also limitations with the use quality scores. Scoring implies some loss of original information and increases observer bias (29). Another possible shortcoming of this review is the omission of the interrater agreement assessment, which may have given a useful numerical estimation of the subjectivity of the assessment of external and internal validity in the original studies.

The most promising magnetic resonance signs in CTS were an increased T2-signal, an increased crosssectional area, and flattening of the median nerve inside the carpal tunnel, as well as bowing of the flexor retinaculum. The heterogeneity and suboptimal quality of the original studies still make reliable assessment of the sensitivity and specificity of these signs impossible. There is an obvious need for MRI studies that use validated diagnostic criteria for CTS and that describe the hand-loading activities during work or leisure time.

\section{References}

1. Atroshi I, Gummesson C, Johnsson R, Ornstein E, Ranstam J, Rosen I. Prevalence of carpal tunnel syndrome in a general population. JAMA 1999;282(2):153-8.

2. Arminio JA. Etiology of carpal: tunnel syndrome. Del Med J 1986;58(3):189-92.

3. Phalen GS. The carpal-tunnel syndrome. Clinical evaluation of 598 hands. Clin Orthop 1972;83:29-40.

4. Stevens JC. The electrodiagnosis of carpal tunnel syndrome. American Association of Electrodiagnostic Medicine [see comments]. Muscle Nerve 1997;20(12):1477-86. AAEM minimonograph, no 26

5. Mesgarzadeh M, Triolo J, Schneck CD. Carpal tunnel syndrome. MR imaging diagnosis. Magn Reson Imaging Clin N Am 1995;3(2):249-64.

6. Sugimoto H, Miyaji N, Ohsawa T. Carpal tunnel syndrome: evaluation of median nerve circulation with dynamic contrastenhanced MR imaging. Radiology 1994;190(2):459-66.

7. Britz GW, Haynor DR, Kuntz C, Goodkin R, Gitter A, Kliot M. Carpal tunnel syndrome: correlation of magnetic resonance imaging, clinical, electrodiagnostic, and intraoperative findings. Neurosurgery 1995;37(6):1097-103.

8. Brahme SK, Hodler J, Braun RM, Sebrechts C, Jackson W, Resnick D. Dynamic MR imaging of carpal tunnel syndrome. Skeletal Radiol 1997;26(8):482-7.

9. The Cochrane Methods Working Group on Systematic Review of Screening and Diagnostic Tests. Recommended methods. Updated 6 June 1996. Available at http:// www.cochrane.org/cochrane/sadtdoc1.htm

10. American Academy of Neurology, American Association of Electrodiagnostic Medicine, and American Academy of Physical Medicine and Rehabilitation. Practice parameter for electrodiagnostic studies in carpal tunnel syndrome (summary statement). Neurology 1993;43(11):2404-5. [Published erratum appears in Neurology $1994 \mathrm{Feb}$;44(2):367.]

11. Quality Standards Subcommittee of the American Academy of Neurology. Practice parameter for carpal tunnel syndrome (summary statement): report of the Quality Standards Subcommittee of the American Academy of Neurology. Neurology 1993;43(11):2406-9.

12. Rempel D, Evanoff B, Amadio PC, de Krom M, Franklin G, Franzblau A, et al. Consensus criteria for the classification of carpal tunnel syndrome in epidemiologic studies. Am J Public Health 1998;88(10):1447-51.

13. Gelberman RH, Rydevik BL, Pess GM, Szabo RM, Lundborg G. Carpal tunnel syndrome: a scientific basis for clinical care. Orthop Clin North Am 1988;19(1):115-24.

14. Bonel HM, Heuck A, Frei KA, Herrmann K, Scheidler J, Srivastav S, et al. Carpal tunnel syndrome: assessment by turbo spin echo, spin echo, and magnetization transfer imaging applied in a low-field MR system. J Comput Assist Tomogr 2001;25(1):137-45.

15. Radack DM, Schweitzer ME, Taras J. Carpal tunnel syndrome: are the MR findings a result of population selection bias? [see comments]. AJR Am J Roentgenol 1997;169(6):1649-53.

16. Bak L, Bak S, Gaster P, Mathiesen F, Ellemann K, Bertheussen $\mathrm{K}$, et al. MR imaging of the wrist in carpal tunnel syndrome. Acta Radiol 1997;38(6):1050-2.

17. Soccetti A, Raffaelli P, Giovagnoni A, Ercolani P, Mercante $\mathrm{O}$, Pelliccioni G. MR imaging in the diagnosis of carpal tunnel syndrome. Ital J Orthop Traumatol 1992;18(1):123-7.

18. Zagnoli F, Andre V, Le Dreff P, Garcia JF, Bellard S. 
Idiopathic carpal tunnel syndrome. Clinical, electrodiagnostic, and magnetic resonance imaging correlations. Rev Rhum Engl Ed 1999;66(4):192-200.

19. Buchberger W, Judmaier W, Birbamer G, Lener M, Schmidauer C. Carpal tunnel syndrome: diagnosis with high-resolution sonography. AJR Am J Roentgenol 1992;159(4):793-8.

20. Allmann KH, Horch R, Uhl M, Gufler H, Altehoefer C, Stark GB, et al. MR imaging of the carpal tunnel. Eur J Radiol 1997;25(2):141-5.

21. Kleindienst A, Hamm B, Lanksch WR. Carpal tunnel syndrome: staging of median nerve compression by MR imaging. J Magn Reson Imaging 1998;8(5):1119-25.

22. Mesgarzadeh M, Schneck CD, Bonakdarpour A, Mitra A, Conaway D. Carpal tunnel: MR imaging. Part II. Carpal tunnel syndrome. Radiology 1989;171(3):749-54.

23. Mesgarzadeh M, Schneck CD, Bonakdarpour A. Carpal tunnel: MR imaging: Part I (Normal anatomy). Radiology 1989;171(3):743-8.

24. Pierre-Jerome C, Bekkelund SI, Husby G, Mellgren SI, Os- teaux M, Nordstrom R. MRI of anatomical variants of the wrist in women. Surg Radiol Anat 1996;18(1):37-41.

25. Pierre-Jerome C, Bekkelund SI, Mellgren SI, Nordstrom R. Quantitative MRI and electrophysiology of preoperative carpal tunnel syndrome in a female population. Ergonomics 1997;40(6):642-9.

26. Rosenbaum RB. The role of imaging in the diagnosis of carpal tunnel syndrome. Invest Radiol 1993;28(11):1059-62.

27. Lijmer JG, Mol BW, Heisterkamp S, Bonsel GJ, Prins MH, van der Meulen JH, et al. Empirical evidence of design-related bias in studies of diagnostic tests. JAMA 1999;282(11):10616.

28. Irwig L, Macaskill P, Glasziou P. Meta-analythic methods for diagnostic test accuracy. J Clin Epidemiol 1995;48:119-30.

29. Greenland S. Invited commentary: a critical look at some popular meta-analytic methods. Am J Epidemiol 1994; 140(3):290-6.

Received for publication: 2 April 2002 